\title{
HUMAN PHARMACOGENETIC PECULARITIES AFFECTING THE ACTION OF ANTI-TUBERCULOSIS MEDICINES
}

\author{
P.B.Antonenko, V.I.Kresyun, G.V.Zaychenko*, V.V.Godovan \\ Odesa National Medical University \\ Institute for Continuing Education of Pharmacy Professionals at the National University \\ of Pharmacy*
}

Key words: genetic polymorphism; tuberculosis; CYP; NAT2

\begin{abstract}
For a long time it is known about differences in efficiency and toxicity of medicines in different patients. This may be due to the genetic polymorphism of the human genes, which determine drug metabolism. In this connection, the study of the genetic polymorphism, which controls the processes of drug biotransformation in human, and its influence on the effectiveness and safety of treatment of different diseases, including tuberculosis (TB), is an important task of clinical pharmacology. The review presents the data on differences of genotypes, which determine the activity of two cytochromes (CYP) 450 - CYP2E1 and CYP2C9, as well as N-acetyltransferase-2 (NAT2) for the concentration in blood of the most effective antituberculosis drugs - isoniazid and rifampicin, for efficiency and toxicity of TB treatment. It has been shown that polymorphism of the CYP2C9, CYP2E1, NAT2, GST, UGT genotype in TB patients can be used as predictors of antitubercular drug-induced liver injuries. Variation of human genes that control transcription of interleukins, interferon- $\gamma$, SLC11A1, etc., allows predicting TB susceptibility and the treatment outcome.
\end{abstract}

Starting from ancient time

Soctors noticed the presence of differences in efficiency and toxicity of one drug in different persons. These differences can be related to the human genetic polymorphism, which determine metabolism and transport of medicines or their pharmacological activity [20]. The genetic polymorphism affects the activity of several cytochromes of (CYP) 450 CYP, such as CYP 2D6, 2C9, 2C19 that can alter efficiency of certain medicines, for example codeine, tamoxifen, clopidogrel, warfarin, etc., and it also affects the enzymes activity of the second phase of biotransformation - thiopurin-methyltransferase, $\mathrm{N}$-acetyltransferase-2 (NAT2) that can alter efficiency of 5-ftoruracil, azathioprin, isoniazid, etc. For today in practical medicine the genetic testing of the CYP2C9 gene is performed before administration of the anticoagulant warfarin, the CYP2C19 gene - before administration of the antiaggregant clopidogrel, etc. [20, 29, 33].
According to polymorphism of NAT2 the individuals may have the rapid, intermediate, or and slow type of acetylation. On the one hand, the genotype of "slow acetylator" can determine development and the clinical course of parodontitis, diabetes mellitus, bronchial asthma, etc. $[7,23]$. On the other hand, the NAT2 polymorhism affects the rate of inactivation and, therefore, the concentration in blood of certain medicines, including antituberculosis drug isoniazid [34]. Thus, determination of the genotype/phenotype of NAT2 can serve as a supplementary method for improving the pharmacotherapy efficiency and minimization of side effects during treatment of certain diseases, for instance tuberculosis (TB). It is very important since according to the incidence of TB (59.5 cases per 100000 of the population in 2014) Ukraine belongs to the countries with a high morbidity, which stipulates medical and social importance of the TB problem in Ukraine [11]. Among

\footnotetext{
P.B.Antonenko - Doctor of Medicine, professor of the Department of General and Clinical Pharmacology of the Odesa National Medical University
}

G.V.Zaychenko - Doctor of Medicine, professor, head of the Department of Clinical Pharmacology of the Institute for Continuing Education of Pharmacy Professionals at the National University of Pharmacy (Kharkiv)

the causes of the TB-treatment failure there is the absence of the individual approach in dosing of antituberculosis drugs in relation to the genetic polymorphism determining biotransformation of antituberculosis agents. According to the DOTS-strategy for TB-treatment adopted in Ukraine in 2006 a daily dose of isoniazid was decreased from $5-15 \mathrm{mg} / \mathrm{kg}$ of the body weight to $4-6 \mathrm{mg} / \mathrm{kg}$. At the same time there is a shortage of information regarding the level of antituberculosis agents in the organism of patients. In most cases the studies indicate a significant prevalence of the sub-effective concentrations of drugs [35]. The main cause of the low concentration of isoniazid in blood of patients can be associated with neglecting the genetic polymorphism that affects biotransformation of antituberculosis drugs. In this connection, the study of the genetic polymorphism, which controls the processes of drug biotransformation in human, and its influence on the effectiveness and safety of treatment of TB is an important task of clinical pharmacology. It will allow to introduce genotyping as a useful tool of optimization of TB pharmacotherapy. 
In carriers of variant alleles *2, *3 according to the $C Y P 2 C 9$ genotype (the so-called "slow metabolizers") the concentration of rifampicin in $4 \mathrm{~h}$ after its administration was by 25.1 and $22.2 \%$ higher than in "intermediate metabolizers" (heterozygote genotypes *1/*2, *1/*3) and "rapid metabolizers" (homozygote genotype ${ }^{*} 1 /{ }^{*} 1$ ), respectively; in $6 \mathrm{~h}$ the concentration of isoniazid was higher by $68.8 \%$ than in "intermediate metabolizers" $(\mathrm{P}<0.05)$ [12]. It indicates decrease of biotransformation of rifampicin and isoniazid in carriers with the genotype of "slow metabolizers", and confirms involvement of this CYP isoforms in the metabolism of the drugs studied. The CYP2C9 enzyme can participate in the metabolism of isonizid as CYP2E1 (Fig. 1). Rifampicin changes into deacetylrifampicin at first, but further metabolites of rifampicin are not exactly known. Thus, CYP isoforms are the putative participants of rifampicin biotransformation.

In carriers with variant genotypes of $C Y P 2 E 1{ }^{*} C D ;{ }^{*} C C$ ("slow metabolizers") there is a higher concentration of isoniazid than in individuals with the wild-type genotype * $D D$ ("rapid metabolizers") $(P>0.05)$ [2]. These data coincide with the data of G.Ramachandran, S.Swaminathan, 2012, according to which CYP2E1 is involved in the metabolism of isoniazid. In "slow metabolizers" the concentration of rifampicin in $6 \mathrm{~h}$ after its administration was also higher by $17.6 \%$ than in the "rapid metabolizers" $(\mathrm{P}<0.05)$. Based on these data it is possible to speak about a certain involvement of the enzyme CYP2E1 in the metabolism of rifampicin and, to a lesser extent, in the metabolism of isoniazid.

In patients with pulmonary $\mathrm{TB}$, who according to the NAT2 genotype belonged to "slow acetylators" (SA), a significantly higher concentration of isoniazid in blood was observed in 4 and $6 \mathrm{~h}$ after its administration by 20.6 and $38.0 \%$ $(\mathrm{P}<0.05)$, respectively, than in "ra-

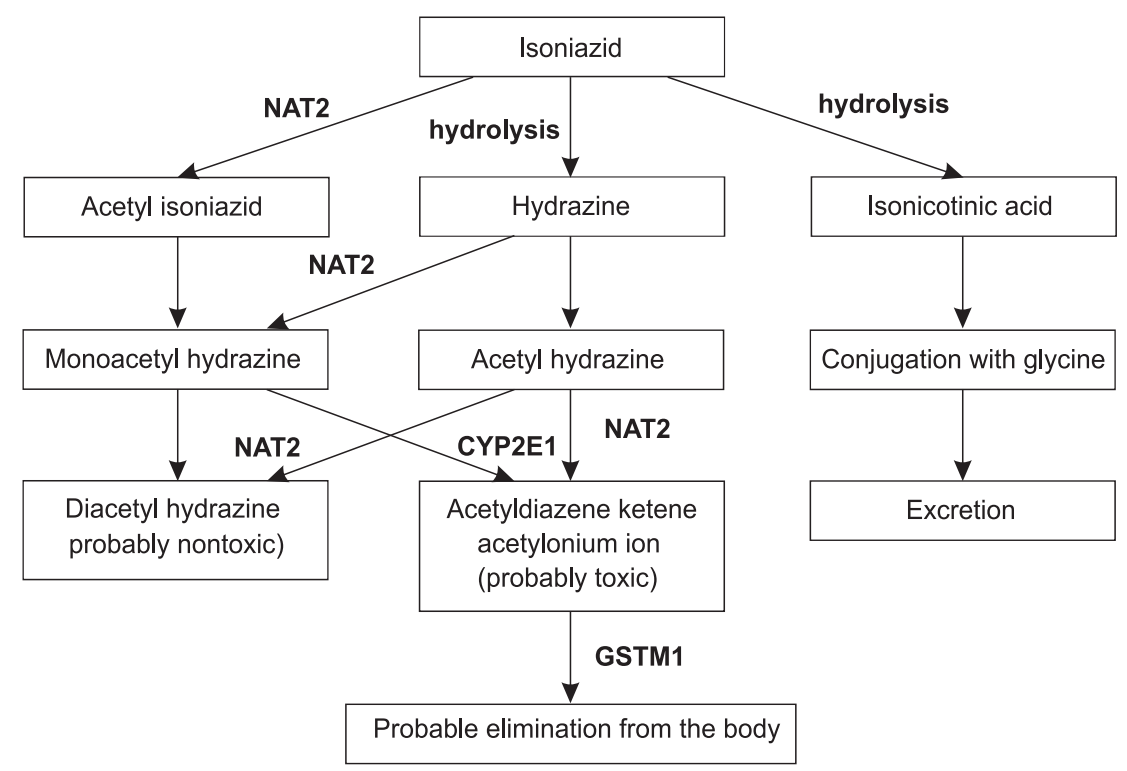

Fig. 1. The putative metabolic cycle of isoniazid (according to Geetha Ramachandran, Soumya Swaminathan, 2012 [27])

pid acetylators" (RA) [6]. The number of patients with the RA genotype, who had the sub-therapeutic concentration of isoniazid, in 6 after its administration was 2 times greater than in SA (42.4 vs $\left.19.6 \% ; \chi^{2}=4.054 ; \mathrm{P}<0.05\right)$. The data presented confirm the importance of determining the NAT2 genotype in TB-patients in order to correct the therapeutic dose of isoniazid. Therefore, detection of the NAT2 genotype in TB-patients provides accurate information for prediction of the acetylator phenotype because of the close relationship between the acetylation genotype and the acetylator phenotype [29].

Marked inter-subject variations of rifampicin concentrations may be associated with single nucleotide polymorphisms of the human transporter gene SLCO1B1 [37]. Variability of carboxylesterase 2, especially c.22263A.G in the promoter region, may also alter rifampicin metabolism by affecting the gene expression [31].

If the gene polymorphism affects the level of antituberculosis drugs in blood of TB-patients, it may also have influence on the effectiveness and toxicity of antituberculosis treatment.

According to the $C Y P 2 C 9$ genotype at the end of in-patient treat- ment the processes of resorption of TB-infiltrates and the absence of pulmonary destruction were observed in "slow metabolizers" [12]. For example, resorption of TB-infiltrates in lungs was observed in $82.8 \%$ of "rapid", $91.0 \%$ "intermediate" and 100\% "slow metabolizers" ( $P>0.05)$. Both at the beginning and at the end of in-patient treatment the activity of gamma-glutaminetransferase (GGT) in the blood plasma usually increased in hepatitis was higher in "slow metabolizers" than in "intermediate metabolizers" by 38.8 and $53.8 \%$, respectively $(\mathrm{P}<0.05)$. It can be explained by high levels of isoniazid and rifampicin in this group [1].

At the beginning of treatment in "rapid metabolizers" according to the CYP2E1 genotype the level of bilirubin in blood was higher than in "slow metabolizers" by $33.2 \%$, the activity of alanine aminotransferase (AlAT) and GGT - by 65.6 and $41.0 \%$, respectively $(\mathrm{P}<0.05)$ [3]. At the end of in-patient treatment the activity of aspartate aminotransferase (AsAT) and AlAT in "rapid metabolizers" was higher than in "slow metabolizers" by 49.5 and $23.9 \%$, respectively $(\mathrm{P}<0.05)$. The high level of hepatotoxicity markers in "rapid metabolizers" can be explained by their more 


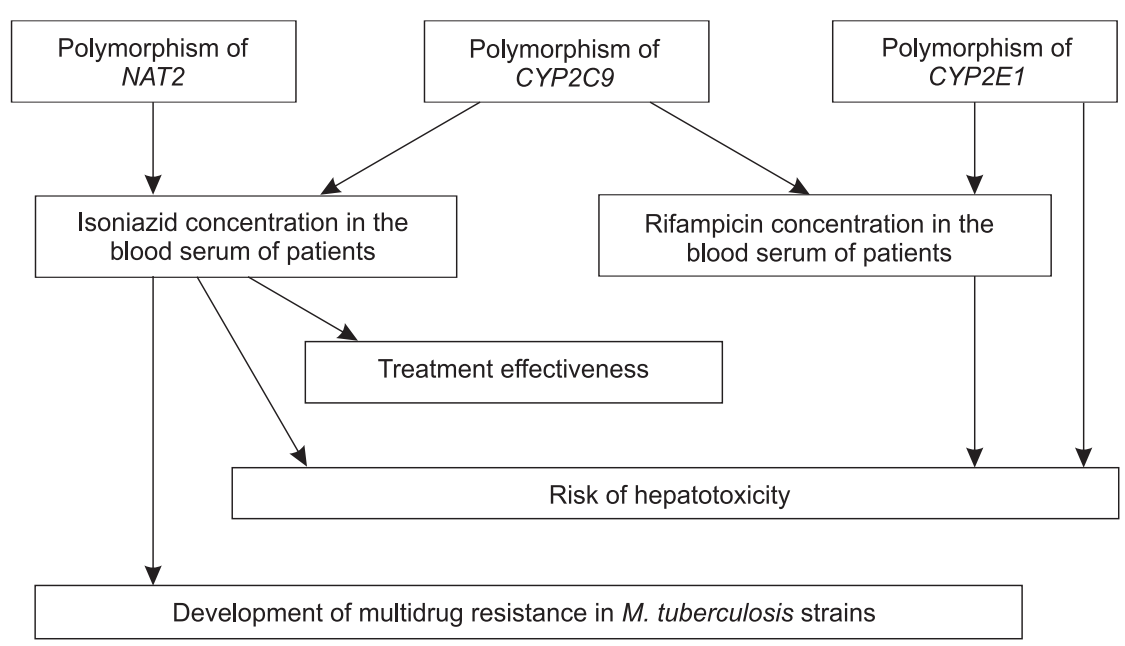

Fig. 2. The effect of the genetic polymorphism of TB-patients on pharmacokinetics of antituberculosis drugs, effectiveness and toxicity of treatment [2]

expressed capability to form toxic metabolites in the liver than in "slow metabolizers" [18, 25, 26]. It is known that CYP2E1 is involved in the cell alteration through the formation of reactive oxidation products and in the metabolism of acetone, benzene, benzopyrene, tetrachloride carbon and other compounds [9]. As a result, there is formation of hydrogen peroxide, free radical peroxide and hydroxyl that can damage organs, primarily the liver. According to G.Ramachandran, S.Swaminathan, 2012, the enzyme CYP2E1 is involved in formation of toxic metabolites of isoniazid. Thus, the existence of association between the genotype of "rapid metabolizers" in patients with pulmonary TB with higher risk of hepatotoxicity in relation to "slow metabolizers" is quite logical. However, some researchers did not find association between the CYP2E1 gene polymorphism and the risk of drug-induced hepatitis [32].

According to NAT2 in carriers of the RA genotype termination of the pulmonary destruction was 1.3 times longer than in SA $(71.75 \pm$ \pm 6.28 against $54.71 \pm 2.83$ days, $\mathrm{P}<0.05$ ) [2]. At the end of in-patient treatment, according to the culture method, in individuals with the SA genotype the bacterioexcretion occurred in 1.2 times faster than in RA (67.14 \pm 3.31 days vs 82.67 \pm 5.94 day, $\mathrm{P}<0.05 ; \mathrm{C}=2.25$ 28.81). This fact confirms more ra- pid achievement of the therapeutic effect in patients with pulmonary TB with the SA genotype than in patients with the RA genotype. At the moment of hospital discharge the activity of markers of the liver damage in SA were higher than in RA. For example, the level of total bilirubin in blood was higher by $17.5 \%(\mathrm{P}<0.01)$, thymol test by $39.8 \%(\mathrm{P}<0.01)$, the activity of AlAT and AsAT - by 23.2 and $26.4 \%$ $(\mathrm{P}<0.01)$, respectively, GGT - by $13.7 \%(\mathrm{P}<0.05)$.

Thus, the presence of the SA genotype was associated with the better therapeutic effect of TB treatment and the greater risk of hepatotoxicity development compared to RA (Fig. 2).

The data obtained coincide with the findings of Azuma J. et al., 2013, according to which selection of the isoniazid dose in relation to the acetylation genotype reduces toxicity and improves the effectiveness of TB treatment [21]. The slow acetylator status of NAT2 as a risk factor for isoniazid-induced hepatotoxicity was observed in the study conducted in the Tunisian patients with tuberculosis [14]. A recent meta-analysis by Wang et al. (2012) of 14 studies showed a significant association between the SA genotype and the risk of antituberculous drug-induced liver toxicity [24].

It is known that NAT2 enzyme metabolizes isoniazid to acetylisoniazid [29]. In SA according to the NAT2 genotype the biotransformation of isoniazid primarily occurs with formation of acetyl isoniazid that is less toxic, and is accompanied by the lower risk of adverse effects of isoniazid [27]. Isoniazid causes disbalance between the prooxidant and antioxidant activity. It can simultaneously increase the level of peroxidation products associated with the isoniazid-induced hepatotoxicity and decrease the activity of the antioxidant system [13]. It is known that principal toxic effects of isoniazid are associated with formation of toxic metabolites - acetyl hydrazine [28], hydrazine and hydrazones [17]. Therefore, it is logical that in carriers with the RA genotype isoniazid mainly transforms into acetyl isoniazid that is less toxic than hydrazine. In addition, the presence of mutated alleles (SA) in TB-patients is associated with a high risk of microalbuminuria - the renal excretory function disorder [5].

One more CYP-isoform can control development of drug-induced hepatotoxicity. The G516T polymorphism in the CYP2B6 gene is a key predictor of the therapeutic response to treatment in TB patients [19].

Glutathione-S-transferases (GSTs) are a group of enzymes involved in detoxification of numerous medicines, including antituberculosis drugs [27]. The negative impact of the GSTM-null and 
GSTT-null genotype in patients with tuberculosis was determined on the processes of detoxification and accumulation of metabolites in the body causing toxicity and allergic reactions [10]. The patients with pulmonary TB the genotypes of del GSTM1 and del GSTT1 are associated with the renal excretory function disorder under the effect of toxic anti-TB drugs. In patients with GSTT1 gene deletion 100\% incidence of the renal excretory function disorders is at the prehospital stage of treatment [5].

Most studies of antitubercular drug-induced liver injuries (ATLI) are focused on the genetic polymorphism of genes encoding metabolic enzymes, including NAT2, GST and CYP450 [16]. However, there are other gene polymorphisms that can affect development of ATLI. Other possible genetic variation mechanisms involve HLA (human leukocyte antigen), UDP glucuronosyltransferase (UGT), etc. The glucuronidation reaction is mediated by UGT. Currently, 15 isoforms of UGT in human are known, and 8 of them are encoded by UGT1A. In the Taiwan population, it was shown that the variants of UGT1A were associated with antituberculosis-induced hepatotoxicity [15].

Probably the immune system also contributes to the onset of ALTI. It was suggested that ATLI was more likely in subjects of the HLA-DQB $1 * 05 / * 05$ genotype system [16]. The logistic regression analysis showed that there was a significantly greater risk of ATLI (OR 8.89; 95\%CI1.36-57.93, P<0.05) in patients with the TT genotype of pregnane $X$ receptor PXR gene (rs3814055) compared to those of the wild-type CC genotype [40].

At the individual level, the differences in the host immune response play critical roles in TB susceptibility and progression. For example, macrophages mediate the host innate immune response to M. tuberculosis through pathogen recognition and activation of an inflammatory response [8, 39]. Mac- rophages also express Toll-like receptors (TLRs) that mediate production of cytokines and act as principal receptors in the innate response to $M$. tuberculosis. Polymorphism of $\mathrm{TLR}_{2}$ is a risk factor for susceptibility to pulmonary TB by different immune mechanisms [39]. Interleukins also play important role in resistance to TB. The results obtained suggest that polymorphism of IL-10 and IL-6 is associated with the increased TB risk in the Europeans and Asians [22]. For instance, the IL-10 $1082 G / A$ polymorphism is associated with the increased TB risk in the Europeans, while the IL-10 - 819C/T and IL-10 - 592A/C polymorphisms in the Asians. However, the IL-6 - 174G/C polymorphism might be a genetic risk factor that decreases TB susceptibility in Asians [22]. In the severe course of TB there is a decrease of interleukin-2 production (IL-2) that is responsible for macrophage activation and initiation of the interferon- $\gamma$ synthesis and at the same time there is an increase of IL-10 expression that has the immunosuppressive activity [4].

The SLC11A1-encoded product is an integral membrane protein that is exclusively expressed in the lysosomal compartment of macrophages and monocytes. The precise role of SLC11A1 in TB disease is still controversial. Li et al. (2011) showed the relationship between TB susceptibility and the $D 543 N$ polymorphism of SLC11A1 [24]. It was found that $D 543 N$ (the G/A genotype) was associated with the treatment failure in patients with pulmonary TB $[\mathrm{OR}=11.61$, 95\%, CI=3.66-36.78] [30]. The presence of the GSTM1 null allele is associated with the chronic form of TB. The percentage contribution of SA in the group of patients with pulmonary TB is significantly higher compared to the group of healthy individuals [4].

It was determined that polymorphisms of CYP2C19 and CYP2E1 in patients with pulmonary TB had no correlation with development of the multidrug resistance (the simultaneous resistance to isoniazid and rifampicin) in strains of M. tuberculosis. Concerning the gene polymorphism of CYP2C9 it should be noted that the multidrug resistant TB occurred in $22.4 \%$ of patients with the genotype of "rapid metabolizers"; in $13.6 \%$ of individuals with the genotype of "intermediate metabolizers" and did not appear in patients with the genotype of "slow metabolizers" [2]. It is noteworthy that patients with the "slow metabolizers" genotype had the highest concentration of isoniazid and rifampicin $(\mathrm{P}<0.05)$ in relation to other genotypes of CYP2C9. According to the NAT2 genotype at the completion of treatment RA had the multidrug resistant $M$. tuberculosis strains in 3.5 times more often than SA (33.3 vs 9.4\%; $\mathrm{P}<0.05$ ).

Thus, the given review presents new information about the effect of the genetic polymorphism in TBpatients regulating drug biotransformation in human on the efficacy and safety of anti-TB treatment.

CONCLUSIONS

1. The screening study of the NAT2 genotype in TB-patients allows to identify the group of patients with the genotype of "rapid acetylators" characterized by a lower efficacy of treatment and a greater risk of appearance of the multidrug-resistant $M$. tuberculosis strains, it determines the need for the individual dose selection of isoniazid in relation to the NAT2 genotype.

2. At the beginning of the antituberculosis treatment it is recommended to determine among patients with pulmonary TB the individuals with the "slow acetylators" genotype of the NAT2 gene, "slow metabolizers" of the CYP2C9 gene, "rapid metabolizers" of the CYP2E1 gene, it allows to select the group of patients with a high risk of adverse reactions, in particular hepatotoxicity that requires a careful monitoring of the liver function and its pharmacological correction. 


\section{REFERENCES}

1. Антоненко П.Б. // Кубанский научный мед. вестник. - 2014. - №2 (144). - С. 12-16.

2. Антоненко П.Б. Вплив поліморфізму процесів біотрансформації ліків на ефективність протитуберкульозної хіміотерапії у людини : Автореф. дис. ... доктора мед. наук : спец. 14.01.28 «Клінічна фармакологія». - Одесса, 2015. - 38 с.

3. Антоненко П.Б. // Одеський мед. журн. - 2014. - №3. - С. 62-67.

4. Бажора Ю.І., Сметюк О.О. // Інтегративна антропол. - 2011. - №2 (18). - С. 7-10.

5. Бажора Ю.І., Сметюк О.О., Кресюн В.Й. // Одеський мед. журн. - 2011. - №5. - С. 38-42.

6. Кресюн В.Й., Філюк В.В., Антоненко П.Б. та ін. // Укр. пульмонол. журн. - 2013. - №3. - С. 24-27.

7. Пат. 54214 Україна, МПК (2006) А 61 В 10/00 Спосіб визначення схильності до пародонтиту в експерименті / С.А.Шнайдер, В.О.Ульянов (Україна); заявник і патентовласник Одес. держ. мед. ун-т. - № и201007715. Заявл.: 21.06.2010. Опубл.: 25.10.2010. - Бюл. №20. - 4 с.

8. Пішак В.П., Польова С.П., Бажора Ю.І., Чеснокова М.М. // Інтегративна антропол. - 2011. - №1 (17). C. 4-11.

9. Рудик Ю.С., Пивовар С.М., Попович А.С., Ніколаєва В.В. // Клінічна фармація. - 2012. - Т. 16, №4. C. 4-10.

10. Тодоріко Л.Д., Сем'янів І.О., Сака А.А. // Молодий вчений. - 2014. - №4. - С. 98-100.

11. Фещенко Ю.І., Мельник В.М., Турченко Л.В. // Укр. пульмонол. журн. - 2015. - №1. - С. 5-9.

12. Antonenko P.B., Kresyun V.I. // Molecular genetics, microbiol. and virol. - 2014. - Vol. 29, №3. - P. 110-114.

13. Boelsterli U.A., Lee K.K. // J. Gastroenterol. Hepatol. - 2014. - Vol. 29. - P. 678-687.

14. Ben Mahmoud L., Ghozzi H., Kamoun A. et al. // Pathol. Biol. (Paris). - 2012. - Vol. 60, №5. - P. 324-330.

15. Chang J.C., Liu E.H., Lee C.N. et al. // Int. J. Tuberc. Lung Dis. - 2012. - Vol. 16. - P. 376-378.

16. Chen R., Zhang Y., Tang S. et al. // J. Clin. Pharm. Ther. - 2015. - Vol. 40, №1. - P. 110-115.

17. Cunningham K., Claus S.P., Lindon J.C. et al. // J. Proteome Res. - 2012. - Vol. 9, №11. - P. 4630-4642.

18. Donald P.R., Parkin D.P., Seifart H.I. et al. // Pharmacokinet. Dispos. - 2007. - Vol. 63, №7. - P. 633-639.

19. Fernandes D.C., Santos N.P., Moraes M.R. et al. // Int. J. Infect. Dis. - 2015. - Vol. 33. - P. 28-31.

20. Heller F. // Acta Clin. Belg. - 2013. - Vol. 68, №2. - P. 77-80.

21. Junichi Azuma, Masako Ohno, Ryuji Kubota et al.//Eur. J. Clin. Pharmacol. - 2013. - Vol. 69. - P. 1091-1101.

22. Ke Z., Yuan L., Ma J. et al. // Yonsei Med. J. - 2015. - Vol. 56, №5. - P. 1274-1287.

23. Klimčáková L., Habalová V., Sivoňová M. et al. // Mol. Biol. Rep. - 2011. - Vol. 38, №2. - P. 1287-1293.

24. Li X., Yang Y., Zhou F. et al. // PLoS One. - 2011. - Vol. 6. - e15831.

25. Nanashima K., Mawatari T., Tahara N., Higuchi N. // Tuberculosis (Edinb). - 2012. - Vol. 92. - P. 253-259.

26. Perwitasari D.A., Atthobari J., Wilffert B. // Drug Metab. Rev. - 2015. - Vol. 47, №2. - P. 222-228.

27. Ramachandran Geetha, Swaminathan Soumya // Pharmacogenomics and Personalized Medicine. 2012. - №5. - P. 89-98.

28. Roy P.D., Majumder M., Roy B. // Pharmacogenomics. - 2008. - Vol. 9, №3. - P. 311-321.

29. Salazar-González R., Gómez R., Romano-Moreno S. et al. // Mol. Biol. Rep. - 2014. - Vol. 41, №12. P. 7833-7843.

30. Salinas-Delgado Y., Galaviz-Hernández C., Toral R.G. et al. // Drug Metabol. Personal. Ther. - 2015. Vol. 30, №3. - P. 211-214.

31. Sang Hoon Song, Ho Eun Chang, Sun Hee Jun et al. // J. Antimicrob. Chemother. - 2013. - Vol. 68, №6. P. 1281-1284.

32. Sharma S.K., Jha B.K., A. Sharma et al. // Int. J. Tuberc. Lung Dis. - 2014. - Vol. 18, №5. - P. 588-593.

33. Shin J. // J. Pharm. Pract. - 2012. - Vol. 25, №4. - P. 428-438.

34. Singh N., Dubey S., Chinnaraj S. et al. // Mol. Diagn. Ther. - 2009. - Vol. 13, №1. - P. 49-58.

35. Van Tongeren L., Nolan S., Cook V.J. et al. // Int. J. Tuberc. Lung Dis. - 2013. - Vol. 17, №2. - P. 221-224.

36. Wang. P.Y., Xie S.Y., Hao Q., Xiang B.F. // Int. J. Tuberc. Lung Dis. - 2012. - Vol. 16, №5. - P. 589-595.

37. Weiner Marc, Peloquin Charles, Burman William et al. // Antimicrobial agents and chemotherapy. 2010. - Vol. 54, №10. - P. 4192-4200. 
38. Wu A.H. // Clin. Proteomics. - 2011. - Vol. 8, №1. - P. 12-16.

39. Zhao Y., Bu H., Hong K. et al. // Int. J. Clin. Exp. Pathol. - 2015. - Vol. 8, №10. - P. 12608-12620.

40. Zazuli Z., Barliana M.I., Mulyani U.A. et al. //J. Clin. Pharm. Ther. - 2015. - Vol. 40, №6. - P. 680-684.

ФАРМАКОГЕНЕТИЧНІ ОСОБЛИВОСТІ ЛЮДИНИ, ЩО ВПЛИВАЮТЬ НА ДІЮ ПРОТИТУБЕРКУЛЬОЗНИХ ПРЕПАРАТІВ

П.Б.Антоненко, В.Й.Кресюн, Г.В.Зайченко

одеський національний медичний університет, Інститут підвищення кваліфікації спеціалістів фармації

Національного фармацевтичного університету*

Ключові слова: генетичний поліморфізм; туберкульоз; СYР; NAT2

Здавна відомо про відмінності в ефективності і токсичності лікарських препаратів у різних хворих. Це може бути пов'язано з генетичним поліморфізмом генів людини, що визначають метаболізм ліків. У зв'язку з цим вивчення генетичного поліморфізму людини, що контролює біотрансформацію, та його вплив на ефективність і безпечність лікування різних захворювань, включаючи туберкульоз (ТБ), є важливим завданням клінічної фармакології. В огляді наводяться дані щодо значення відмінностей генотипів, які визначають активність двох цитохромів (CYP) 450 - CYP2E1 і CYP2C9, а також N-ацетилтрансферази-2 (NAT2), для вмісту найбільш ефективних протитуберкульозних препаратів ізоніазиду і рифампіцину для ефективності і токсичності лікування ТБ. Показано, що поліморфізм генотипів CYP2C9, CYP2E1, NAT2, GST, UGT у хворих на ТБ може використовуватись як предиктор ураження печінки, спричинене протитуберкульозними препаратами. Варіативність генів людини, що контролюють транскрипцію низки інтерлейкінів, інтерферону- $\gamma$, SLC11A1 тощо, допомагає передбачати схильність до розвитку ТБ і ефективність його лікування.

\section{ФАРМАКОГЕНЕТИЧЕСКИЕ ОСОБЕННОСТИ ЧЕЛОВЕКА, КОТОРЫЕ ВЛИЯЮТ НА ДЕЙСТВИЕ ПРОТИВОТУБЕРКУЛЕЗНЫХ ПРЕПАРАТОВ}

П.Б.Антоненко, В.И.Кресюн, А.В.Зайченко*, В.В.Годован

Одесский национальный медицинский университет, Институт повышения квалификации специалистов фармации Национального фармацевтического университета*

Ключевые слова: генетический полиморфизм; туберкулез; СYP; NAT2

Издавна известно об отличиях в эффективности и токсичности лекарственных препаратов при лечении разных больных. Это может быть связано с генетическим полиморфизмом генов человека, которые определяют метаболизм лекарств. В связи с этим изучение генетического полиморфизма человека, который контролирует биотрансформацию, и его влияние на эффективность и безопасность лечения различных заболеваний, включая туберкулез (ТБ), является важнейшим заданием клинической фармакологии. В обзоре приводятся данные относительно отличий генотипов, которые определяют активность двух цитохромов (СҮР) 450 - СYР2E1 и CYP2C9, а также N-ацетилтрансферазы-2 (NAT2) для содержания наиболее эффективных противотуберкулезных препаратов изониазида и рифампицина для эффективности и токсичности лечения ТБ. Показано, что полиморфизм генотипов CYP2C9, CYP2E1, NAT2, GST, UGT у больных ТБ может использоваться как предиктор поражения печени, вызванного противотуберкулезными препаратами. Вариативность генов человека, которые контролируют транскрипцию ряда интерлейкинов, интерферона- $\gamma$, SLC11A1 и т.д., позволяет предвидеть склонность к развитию ТБ и эффективность его лечения.

Address for correspondence:

Received in 08.02.2016

2, Valihovsky lane, Odesa, 65082.

Tel. (48) 717-35-45. E-mail: peterantonenko@yandex.ru.

Odesa National Medical University 